\title{
Difficulties in Translating Culturally Bound Conversational Words and Phrases in English and Kurdish
}

\author{
Abdul-Nafi' Khidhir Hasan ${ }^{1}$ \\ ${ }^{1}$ Department of English Language, College of Basic Education, Salahaddin University- Erbil, Kurdistan region, Iraq
}

\begin{abstract}
The purpose of conducting this study is to identify and handle the problems arising from translating conversational words and phrases rooted in culture from English into Kurdish and vice versa. To achieve the objectives of the current research, source language conversational texts associated with greetings, politeness terms, kinship terms, address terms and words and phrases used on different occasions are translated into their counterparts in the target language. The results obtained from the translations show that translating cultural concepts is problematic and burdensome, and the problems identified result from cultural differences between the two languages and from literal translation which often leads to unnatural and incomprehensible expressions although this technique is used to borrow a source language expression. The results also indicate that translating culturally-bound conversational words and phrases requires good knowledge and mastery of both languages and cultures and proper use of various translation techniques. This research paper is an attempt to identify the problems that arise in translating culturallyspecific conversational words and phrases from English into Kurdish and vice versa. It also aims to find out effective ways of overcoming the problem through implementing appropriate techniques for translating culturally-loaded words and phrases associated with greetings, terms of address, politeness terms, family relationship, in both languages.
\end{abstract}

KEY WORDS: Conversation, Culturally-Bound, Phrase, Translation Techniques, Words

\section{INTRODUCTION}

As far as the role of translation and interpretation is concerned, the Common European Framework of Reference for Languages is concerned not only with the four basic language skills, but it also expects translation and interpretation to become a skill in a multilingual world through which speakers of two languages

Koya University Journal of Humanities and Social Sciences (KUJHSS).

Volume 3, Issue 1, 2020.

Received 10 July 2018; Accepted 10 July 2019, Regular research paper: Published 28 June 2020

Corresponding author's e-mail: abdulnafi.hasan@su.edu.krd Copyright (C2020 Abdul-Nafi' Kh. Hasan. This is an open access article distributed under the Creative Commons Attribution License. communicate (Pym et al, 2013). They further state that the relatedness between translation and language learning is based on the three models, 1) translation and language learning are opposites because people do not need to learn other languages by virtue of an automatic translator, 2) translation and language learning are complementary skills, in that translation is required because not everyone learns all languages and similarly language learning is required to ensure the availability of translators, and 3) translation is an inherent part of language learning since it is a skill practiced side by side with the four language skills, listening, speaking, reading and writing. Kelly also appreciates the significance of translation stating that it has been argued that "Western Europe owes its civilization to translators" (Cited in Alexander, 2005). Concerning a translator's role, Nida indicates that a translator is someone who facilitates the conveyance of the message, meaning, and cultural aspects from one language into 
another and constructs an equivalent response for receivers (Cited in Dweik and Suleiman, 2013).

Translation of culture has received a great deal of translators' and researchers' attention. In this regard, it is suggested that instead of replacing one form of words by another, translators are capable of improving our understanding of development issues and indigenous cultures by mediating ideas across cultural and national boundaries (Bernacka, 2012). The scope of translation studies has also been broadened by including the culture of the source language and that of the target language (Al-Hassan, 2013). He adds that the linguistic fact recognized by every scholar is that it is difficult or probably impossible to separate language from culture, and both language and culture are involved in translation as a result, as in this example, the Kurdish word, xezan (خَّيَان) literally means family, but in some contexts, it means wife.

Practical problems arise when translation of culture is carried out, especially when the translator belongs to a culture that is completely different from that of the author (Dweik and Suleiman, 2013). One of the problems identified is that some words and phrases representing objects, facts, phenomena and the like are so deeply rooted in culture and so specific to their culture that they have no equivalent in the target culture because they are not known and they are not yet codified in the target language (Guerra, 2012). As a result of the fact that the languages involved in translation are not identical, difficulties in finding an accurate equivalent to cultural concepts can arise (Braçaj, 2015). Translators' being aware of such situations helps them to convey the culture from the source language to the target language (Ibid). Another problem that might arise with respect to translating culture specific concepts is when to translate into nearest equivalent, when to paraphrase, when to borrow expressions from the source language, when to transcribe (Braçaj, 2015; Ghazala, 1995).

In many cases, literal translation of everyday conversational phrases and words from one language into another does not work and results in unnaturalness or misunderstanding. As mentioned previously, this is due to the fact that languages are linguistically and culturally different. Translating culture includes aspects that range from lexical content and syntax to ideologies and ways of life (Glodjović, 2010). Glodjović goes further and states that the translator should decide what cultural aspects are important or desirable to translate and to what extent they should be translated.

This research paper is an attempt to identify the problems that arise in translating culturally-specific conversational words and phrases from English into Kurdish and vice versa. It also aims to find out effective ways of overcoming the problem through implementing appropriate techniques for translating culturally-loaded words and phrases associated with greetings, terms of address, politeness terms, family relationship, in both languages. This research tries to answer these questions:

1. To what extent do English conversational words and phrases have equivalents in Kurdish and vice versa?

2. How is the word or phrase that does not have an equivalent in the target language translated?

3. What are the challenges of translating culture bound terms?

4. What are the strategies that can be used to overcome the difficulties that arise from translating culture?

\section{THEORETICAL BACKGROUND}

Translation is defined as translation can refer to the text that is translated or the act of producing translation (Munday, 2008). In the process of translation between two languages, a translator changes an original written text, that is, the source text in the original verbal language into a written text or the target text in a different verbal language (Ibid). Translation can be classified into three types which include intra-lingual translation in which texts within the same language are reworded or rephrased, inter-lingual translation which is an interpretation of verbal signs by means of another language, and inter-semiotic translation in which an interpretation of verbal signs is given by means of signs of non-verbal sign system, for example, translating a written text into music, painting, and film (Jakobson, cited in Ibid).

Translation has traditionally been viewed as an interlingual communication (Liu, 2012). In contrast, some translation theorists, e.g. Hans J. Vermeer reject the view that translation is a matter of language, but they consider it a matter of cross-cultural or intercultural communication (Bassnett and Lefevere, cited in Ibid). Therefore, it is necessary for the translator to have adequate knowledge about the culture since the words and texts which are translated are situated in a culture (Ukpong, 2017). Ukpong further states that every community has its specific culture and this culture is responsible for defining and shaping people's viewpoints about every segment of life. Culture is considered as the way of people's life which includes attitudes, values, beliefs, arts, sciences, their styles of thinking and habits of thought and activity (Blackburn, cited in Ukpong, 2017). presents another definition stating that culture is the way of people's life and its reflections that are restricted to a community that uses a certain language as a medium of expression (Newmark, 1988).

Understanding the culture of a language helps the speaker to maintain a close contact with the language community of that language and to become an insider to the culture (Dehghani, 2009). This strategy side by side with the translation techniques described below, can be 
implemented to address the problems that arise when translating into a target language or speaking a foreign language.

Gaber suggests five techniques that can be used for translating culturally-bound words and phrases (Cited in Dweik and Suleiman, 2013). These techniques include:

1) Using Cultural Equivalent words or phrases, e.g. translating "nit-picking" into its Kurdish equivalent, "hamu: śtek ba da:waban wadaka:/(بdموشتيك)" كه "(بهداومبهن وه shich literally means "He/She gets everything into the thread."

2) Functional Translation whereby a translator uses a word or phrase that has the same function,

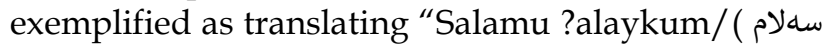
(وعه له يكوم "which literally means "Peace be on you" into "Hello."

3) Paraphrasing in which the word or phrase of the source language is explained in the target language, e.g.,"magi:ra:ni: daka:/(مه كيرانى (م0) ") is explained in English as "A pregnant woman (or she) craves certain food."

4) Glossing is a technique whereby the translator writes footnotes to explain cultural words and expressions. For example, "binawa:n/(بنهوان)" can be defined in a footnote as "a man's wife, mother, sister, aunt or grandmother who lives with him and keeps house for him."

5) Borrowing is transcribing the borrowed word in the target language letters, e.g., the word radio is transcribed as "ŕa:dıo/(راديو)." Borrowing also means to literally translate the source language expression into the target language, e.g., translating crocodile tears into "fırméski: tımsah/(فرميسكى تيمساح)".

6) Another technique which can also be used for translation is called: Modulation, according to which a translator translates into a phrase which is different from the source language and the target language to convey the same meaning (. J, (ND).

Some of the techniques mentioned above are employed in Section III below since they are applicable to translating culturally specific items used in every day conversation. In translating each word, phrase or expression of this type, the technique employed is fit for the context in which the item is used.

\section{METHODOLOGY AND DISCUSSION}

In this section, culturally-bound words and phrases used in everyday conversation are translated from Kurdish into English and vice versa in these respects:

1. A suitable technique is employed for translating each item.

2. The context in which it is used is thoroughly described.

3. The phrases and words are translated from Kurdish in this way: a. They are literally translated into the target language.

b. They are translated into their corresponding terms and phrases in the target language.

c. When there is absence of correspondence in the target language, source language phrases and words are not translated into the target language, instead, they are described

4. English words and phrases are directly translated into their counterparts in Kurdish.

\subsection{Greeting Words and Phrases:}

\begin{tabular}{lll} 
Kurdish & Literal Meaning & English \\
\hline \hline roź ba:ś. • & Good day. & Hello. \\
\hline \hline
\end{tabular}

Context: You use this phrase when you meet or greet someone during the daytime. Technique used: Functional equivalent.

\begin{tabular}{lcl} 
Kurdish & Literal Meaning & English \\
\hline \hline śaw ba:ś. · شهوباش & Good night. & Hello \\
\hline \hline
\end{tabular}

Context: You use this phrase when you meet or greet someone at nighttime. Technique used: Functional equivalent.

\begin{tabular}{lcc} 
Kurdish & Literal Meaning & English \\
\hline \hline salamu ?alaykum. & May peace be upon & Hello. \\
سهلام وعهلهيكوم & you! & \\
\hline \hline
\end{tabular}

Context: You use this phrase when you meet or greet someone anytime. Technique used: Functional equivalent.

\begin{tabular}{ccc} 
Kurdish & Literal Meaning & English \\
\hline \hline sala:m, sar ća:wm. & Sala:m, & Hello \\
سهلام، سهرحاوم & upon my eyes. & $\begin{array}{c}\text { you are } \\
\text { welcome. }\end{array}$ \\
\hline \hline
\end{tabular}

Context: It is used as a response to "Salamu ?alaykum. . (Hello). Technique used: Functional equivalent.

\begin{tabular}{|c|c|c|}
\hline Kurdish & Literal Meaning & English \\
\hline ma:ndu: nabi:. · ماند ونه بي & $\begin{array}{l}\text { May you not be } \\
\text { tired! }\end{array}$ & \\
\hline $\begin{array}{l}\text { ماند ونه بن. (2nd } \\
\text { ma:ndu: nabin } \\
\text { (2nd person plural) }\end{array}$ & $\begin{array}{l}\text { May you not be } \\
\text { tired! }\end{array}$ & \\
\hline
\end{tabular}

(Dehghani 2009, p. 6)

Context: The first phrase is used when you greet someone who is in the middle of doing some work. The 
second is used when you greet people who are in the middle of doing some work. Technique used: Glossing

\begin{tabular}{|c|c|c|}
\hline Kurdish & Literal Meaning & English \\
\hline 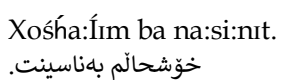 & $\begin{array}{l}\text { Pleased to know } \\
\text { you. }\end{array}$ & $\begin{array}{l}\text { Pleased/Nice } \\
\text { to meet you. }\end{array}$ \\
\hline
\end{tabular}

Context: This phrase is used to greet someone politely when you have just met them for the first time. Technique used: Functional equivalent.

\begin{tabular}{lll} 
Kurdish & Literal Meaning & English \\
\hline \hline $\begin{array}{l}\text { Xośha:Írm ba bi:ni:nit. } \\
\text { خوَشحالمّ بهبينينت }\end{array}$ & Pleased to see you. & Nice to see you. \\
\hline \hline
\end{tabular}

Context: It is used for greeting someone who you already know. Technique used: Functional equivalent.

\begin{tabular}{|c|c|c|}
\hline Kurdish & Literal Meaning & English \\
\hline 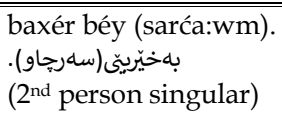 & $\begin{array}{l}\text { Welcome, } \\
\text { (upon my eyes). }\end{array}$ & \\
\hline 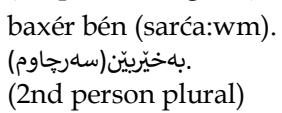 & $\begin{array}{l}\text { Welcome, } \\
\text { (upon my eyes). }\end{array}$ & ............ \\
\hline
\end{tabular}

Context:You use this phrase to welcome a guest or guests. Technique used: Glossing

\subsection{Polite Words and Phrases}

The literal meaning of culturally-bound words and phrases may differ from their meaning in considering the context in which they are used (Dehghani 2009, p. 3). He adds that nearly all the terms and phrases expressing politeness are idiomatic and they are difficult to translate literally into the target language. The translations below show that literal translation of such terms and phrases does not convey their true meaning.

\begin{tabular}{lll} 
Kurdish & Literal Meaning & English \\
\hline \hline ba sar ća:w. •به سله & Upon my eyes & With pleasure \\
\hline \hline
\end{tabular}

Context: The phrase is used when someone is willing to do something for someone. Technique used: Functional equivalent.

The meanings that the phrases, farmu: فهرمو and farmu:n فهرمون express depend on the contexts in which they are used as follows (Ibid):

\begin{tabular}{lcc}
\multicolumn{1}{c}{ Kurdish } & Literal Meaning & English \\
\hline \hline $\begin{array}{l}\text { farmu:. . } \\
\text { (2nd } \text { person singular })\end{array}$ & $\ldots \ldots \ldots \ldots \ldots \ldots$ & How can I help you? \\
farmu:n. . & $\ldots \ldots \ldots \ldots \ldots$ & How can I help you? \\
$\left(2^{\text {nd }}\right.$ person plural $)$ & $\ldots \ldots \ldots \ldots \ldots \ldots$ & \\
\hline \hline
\end{tabular}

Context: When a customer enters a shop or store and says hello, the salesperson says to him/her farmu:.

\begin{tabular}{|c|c|c|}
\hline Kurdish & Literal Meaning & English \\
\hline $\begin{array}{l}\text { farmu:. فهرمو. } \\
\text { (2nd person singular) }\end{array}$ & & Please come in. \\
\hline $\begin{array}{l}\text { farmu:n. فهرمون } \\
\text { (2nd person plural) }\end{array}$ & .............. & Please come in. \\
\hline
\end{tabular}

Context: It is used in the imperative. When you admit a person into your house, office, etc. you say farmu: (Collins English Dictionary).

\begin{tabular}{|c|c|c|}
\hline Kurdish & Literal Meaning & English \\
\hline $\begin{array}{l}\text { farmu:. فهرمو (2nd person singular) } \\
\text { (2nd }\end{array}$ & .. & Here you are. \\
\hline
\end{tabular}

Context: It is a polite way to give something to someone. For example, When a shopkeeper or salesperson gives a purchased item to a customer, he says farmu:, and similarly, when the customer pays money, he says to the shopkeeper farmu:

\begin{tabular}{lll} 
Kurdish & Literal Meaning & English \\
\hline \hline $\begin{array}{l}\text { farmu:. . فd } \\
\left(2^{\text {nd }} \text { person singular }\right)\end{array}$ & $\ldots \ldots \ldots \ldots \ldots \ldots$ & $\begin{array}{l}\text { Go on/ } \\
\text { continue. }\end{array}$ \\
\hline \hline
\end{tabular}

Context: When you ask someone to start talking again after interrupting him/her, you say farmu:

\begin{tabular}{ccc}
\multicolumn{1}{c}{ Kurdish } & Literal Meaning & English \\
\hline \hline $\begin{array}{l}\text { farmu:. . . } \\
\left(2^{\text {nd }} \text { person singular }\right)\end{array}$ & $\ldots \ldots \ldots \ldots \ldots \ldots \ldots$ & After you. \\
\hline
\end{tabular}

Context: When you arrive at a door at the same time as someone else and you let them go through the door first, you say farmu:(The Free Dictionary).

\begin{tabular}{|c|c|c|}
\hline Kurdish & Literal Meaning & English \\
\hline $\begin{array}{l}\text { farmu: da:ni:śa. } \\
\text { فهرمو دانيشه } \\
\text { (2nd person singular) }\end{array}$ & & \\
\hline $\begin{array}{l}\text { farmu: da:ni:śin. } \\
\text { فهرودانيشن. }\end{array}$ & …............ & Please sit down. \\
\hline (2nd person singular) & & \\
\hline
\end{tabular}

Context: When you enter somewhere and the person inside offers you a seat and says farmu: da:ni:śa meaning "please sit down" (Dehghani, 2009).

The technique used in translating farmu: and farmu:n is Functional equivalent.

\begin{tabular}{|c|c|c|}
\hline Kurdish & Literal Meaning & English \\
\hline $\begin{array}{l}\text { farmu:. فهرمو. } \\
\text { (2nd person singular) }\end{array}$ & ב... & "Please, help yourself \\
\hline $\begin{array}{l}\text { farmu:n.. فهرمون } \\
\text { (2nd person plural) }\end{array}$ & $\ldots \ldots$ & $\begin{array}{l}\text { Please, help } \\
\text { yourselves. }\end{array}$ \\
\hline
\end{tabular}

Context: This expression is used to offer food to someone. Technique used: Functional equivalent 


\begin{tabular}{|c|c|c|}
\hline Kurdish & Literal Meaning & English \\
\hline $\begin{array}{l}\text { brbu:ra. ببوره } \\
\text { (2nd person singular) }\end{array}$ & Forgive me. & (I am) sorry. \\
\hline $\begin{array}{l}\text { bibu:rin. ببورن. } \\
\text { (2nd person plural) }\end{array}$ & Forgive me. & (I am) sorry. \\
\hline
\end{tabular}

Context: This phrase is used when you apologize to someone or some people for doing something wrong. Technique used: Functional equivalent

\begin{tabular}{|c|c|c|}
\hline Kurdish & Literal Meaning & English \\
\hline $\begin{array}{l}\text { brbu:ra qisat dabŕm, } \\
\text { ببورقسهات دهبرم، } \\
\text { (2nd person singular) }\end{array}$ & Forgive me. & $\begin{array}{l}\text { Excuse me } \\
\text { interrupting, }\end{array}$ \\
\hline $\begin{array}{l}\text { bibu:rin qisata:n dabŕm, } \\
\text { بورن قسه تان دهبرم، } \\
\text { (2nd person plural) }\end{array}$ & Forgive me. & $\begin{array}{l}\text { Excuse me } \\
\text { interrupting, }\end{array}$ \\
\hline
\end{tabular}

(Collins English Dictionary)

Context: This phrase is used as a polite way of starting to interrupt someone. Technique used: Functional equivalent

\subsection{Words and Phrases for Occasions}

\begin{tabular}{|c|c|c|}
\hline Kurdish & Literal Meaning & English \\
\hline 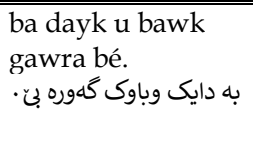 & $\begin{array}{l}\text { May the baby be } \\
\text { brought up by long- } \\
\text { lived father and } \\
\text { mother. }\end{array}$ & \begin{tabular}{l}
\multicolumn{2}{l}{ Congratulations } \\
(on your new \\
baby).
\end{tabular} \\
\hline
\end{tabular}

(Writing Greeting Card Messages, p. 13)

Context: This phrase is used to congratulate a father and mother on the birth of their new baby. Technique used: Functional equivalent.

\begin{tabular}{|c|c|c|}
\hline Kurdish & Literal Meaning & English \\
\hline 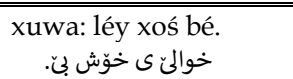 & $\begin{array}{l}\text { May God forgive } \\
\text { him/her! }\end{array}$ & My condolences. \\
\hline xota:n xoś bin. & May you live long. & My condolences. \\
\hline 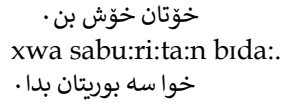 & $\begin{array}{l}\text { May God give you } \\
\text { patience. }\end{array}$ & My condolences. \\
\hline
\end{tabular}

Context: These phrases are used to express condolences. Technique used: Functional equivalent

\begin{tabular}{|c|c|c|}
\hline Kurdish & Literal Meaning & English \\
\hline $\begin{array}{l}\text { ća:wta:n ŕu:n. } \\
\text { جاوتان رِون · }\end{array}$ & $\begin{array}{l}\text { May your eyes gleam } \\
\text { with happiness. }\end{array}$ & $\begin{array}{l}\text { e.g., Congratulations } \\
\text { (on your recent release } \\
\text { from prison). }\end{array}$ \\
\hline
\end{tabular}

(Thinking of your memes-Congratulations on your recent release from prison)

Context: This phrase is used to congratulate family members on the following occasions:

- A family member has just been released from prison,

- A family member was missing and has eventually been found safe, or

- A family member has just got out of serious trouble.

Technique used: Functional equivalent
3.4 Kinship Terms

\begin{tabular}{|c|c|c|c|}
\hline Kurdish & & Definition & English \\
\hline "ma:m & مام & paternal uncle & "uncle \\
\hline xa:Í & خالّ & maternal uncle & uncle \\
\hline $\begin{array}{l}\text { pu:r, mi:mik, } \\
\text { pilık }\end{array}$ & ميمكى، & $\begin{array}{l}\text { the sister of } \\
\text { someone's father or } \\
\text { the sister of } \\
\text { someone's mother }\end{array}$ & aunt \\
\hline ma:moźın & ماموّرَن & paternal uncle's wife & aunt \\
\hline xa:Íoźın & خالّوَرْن & maternal uncle's wife & aunt \\
\hline kứama:m & كوريه مام & paternal uncle's son & cousin \\
\hline kıćama:m & كجهَ مام & $\begin{array}{l}\text { paternal uncle's } \\
\text { daughter }\end{array}$ & cousin \\
\hline kuŕaxa:Í & كورِخالّ & maternal uncle's son & cousin \\
\hline kıćaxa:Í & كجه خال & $\begin{array}{l}\text { maternal uncle's } \\
\text { daughter }\end{array}$ & cousin \\
\hline kứapu:r & كوري يور & $\begin{array}{l}\text { paternal or maternal } \\
\text { aunt's son }\end{array}$ & cousin \\
\hline kıćapu:r & كجه بور & $\begin{array}{l}\text { paternal or maternal } \\
\text { aunt's daughter }\end{array}$ & cousin \\
\hline a:waÍza:wa: & ئاوه لزاوا & $\begin{array}{l}\text { the husband of your } \\
\text { wife's sister }\end{array}$ & $\begin{array}{l}\text { co-brother } \\
\text { (Macmillan } \\
\text { Dictionary) }\end{array}$ \\
\hline hawgiya:n & هه وكيان & $\begin{array}{l}\text { the wife of your } \\
\text { husband's brother }\end{array}$ & $\begin{array}{l}\text { co-sister } \\
\text { (Macmillan } \\
\text { Dictionary) }\end{array}$ \\
\hline bra:y śi:ri: & براى شيرى & $\begin{array}{l}\text { a male who is not a } \\
\text { son of your parents, } \\
\text { but was breastfed by } \\
\text { your mother }\end{array}$ & $\begin{array}{l}\text { foster } \\
\text { brother }\end{array}$ \\
\hline xuśki: śi:ri: & خ خوشى & $\begin{array}{l}\text { a female who is not a } \\
\text { daughter of your } \\
\text { parents, but was } \\
\text { breastfed by your } \\
\text { mother }\end{array}$ & foster sister \\
\hline
\end{tabular}

The English phrase, foster brother is not a total equivalent to the Kurdish, bra:y śi:ri: (براى شيرى). The term in English refers to someone who is not a son of your parents, but is brought up in your family, while that of Kurdish indicates that the person in question is not a son of your parents, but was breastfed by your mother. The same is true of the relation between foster sister and xuśki: śi:ri: (خوشكى شيرى). Technique used: Partially functional equivalent

\subsection{Address Terms}

According to Macmillan dictionary, to address means to call someone a particular name or title when you speak to them, exemplified as "The prince should be addressed as Sir at all times".

\section{English: Mr. Kurdish: ka:k/baŕéz}

Longman Dictionary of Contemporary English states that Mr. is used before a man's family name when you speak to him, write to him or talk about him, e.g., Mr. Smith or Mr. John Smith is the head-teacher. Mr. is also used to address a man in an official position, e.g., Mr. Chairman. Mr. can be translated into ka:k (mainly spoken) or baŕéz (mainly written) which, contrary to 
Mr., comes before first name. For example, ka:k John is correct, but ka:k Smith is wrong in Kurdish culture. Technique used: Functional equivalent.

\section{English: Mrs., Miss, Ms. Kurdish: xa:n, xa:tu:}

Mrs., Miss and Ms. are used to politely address women. Mrs. is used in front of a married woman's family name, Miss is used before an unmarried woman's family name, and Ms.is used before a woman's family name whether she is married or not. Mrs., Miss and Ms. can be replaced by the Kurdish address terms, $x a: n$ and $x a: t u$ : as follows:

$x a: n$ follows a woman's first name whether she is married or not, whereas $x a: t u$ : precedes the first name of a married or unmarried woman, xa:tu: na:zda:r or na:zda:r $x a: n$. Technique used: Functional equivalent.

\section{English: Ma'am Kurdish: $x a: t u: n, x a: n ı m$}

$M a^{\prime} a m$ is used to address a woman in a respectful way, e.g. May I help you, Ma'am (Longman Dictionary of Contemporary English)? xa:tu:n and xa:nım have the same function as ma'am in social contexts in Kurdish. Technique used: Functional equivalent.

\section{English: Miss, Sir, Professor Kurdish: ma:mosta:}

According to Longman Dictionary of Contemporary English, children refer to a female teacher as Miss whether or not she is married, and to a male teacher as Sir, exemplified as I know the answer Miss. and Sir, I have forgotten my homework. Harzing (2016, NP) concluded that in the UK, addressing a university teacher as e.g. Peter/Maria (calling a teacher by his/her first name) is the preferred first choice, addressing him/her as $D r$. Smith the preferred second choice, and addressing him/her as e.g. Mr./Mrs. Smith took the third place. In the USA, the address terms used for university teachers are Dr. Smith which takes the first place, Professor Smith, the preferred second option, and Professor, the preferred third choice (Ibid). In Kurdish, ma:mosta: which literary means teacher is the address term students use when they politely speak to their teachers, but a $\mathrm{PhD}$ holder is also addressed as duktor meaning doctor (Not a medical doctor, however). Technique used: Functional equivalent.

\section{CONCLUSIONS}

It is concluded that:

1. Most culturally bound conversational words and phrases in Kurdish can be rendered into functional equivalents in English and vice versa, but a few items do not have equivalents, e.g., Kurdish, baxér béy or they have to be translated into partial equivalents, exemplified as English, foster brother.

2. Translation of culturally specific words and phrases associated with conversation are problematic and burdensome, and pose a challenge for translators, interpreters and those who speak the target language as follows:

a. Literal translation of some words and phrases results in forms that make no sense or that are unnatural and incomprehensible expressions e.g., translating the Kurdish phrase, ma:ndu: nabi: into May you not be tired!

b. In some cases, the translated concept does not have a total equivalent, therefore it is rendered into a partial equivalent in the target language, as in translating the Kurdish phrase, bra:y śi:ri: which literary means brother through breastfeeding into foster brother.

c. Some phrases or words in the source language correspond to several terms in the target language, for example, the Kurdish phrase, farmu: corresponds to several English phrases which are used in different contexts.

d. In translating some terms, the problem of absence of correspondence arises, for example translating Kurdish, ma:ndu: nabi: into English. In such cases, the term is defined in the target language.

3. Translation of such expressions and phrases requires not only skills but also sufficient information about the culture of people speaking the target language. An accurate translation can be achieved through mastery of the source and target language and through understanding the meaning behind the words, phrases, idioms, slang and the like. Doing an accurate translation also requires using an appropriate translation technique in each situation and context.

4. The translation technique used most is functional equivalent and the least used technique is glossing. In a few situations, phrases are translated into their partial equivalents.

\section{REFERENCE}

Alexander, Neville (2005). The potential role of translation as social practice for the intellectualization of African languages. https://www.marxists.org/archive/alexander/2005-potentialrole-of-translation.pdf. Retrieved on September 4, 2018, p. 6.

Al-Hassan, Ahmad (2013). The Importance of Culture in Translation: Should Culture be Translated? International Journal of Applied Linguistics and English Literature, Vol. 2, No. 2, p. 98.

Bernacka, Anna (2012). The Importance of Translation Studies for Development Education. A Development Education Review, Issue 14, p. 110. 
Braçaj, Morena (2015). Procedures of Translating Culture-Specific Concepts. Mediterranean Journal of Social Sciences, Vol. 6, No., 1 S, pp. 476 and 477.

Cambridge Dictionary. Available at https://dictionary.cambridge.org/dictionary/english. Retrieved on September 23, 2018.

Collins English Dictionary. Available at: https://www.collinsdictionary.com/dictionary/english. Retrieved on September, 20th 2018.

Dehghani, Yavar (2009). Challenges in Translating Culturally Loaded Words and Phrases. Paper Presented at the Australian Association for Research in Education AARE Annual Conference, Canberra, pp. 2, 3, 5 and 6.

Dweik, Bader S. and Maisa Suleiman (2013). Problems Encountered in Translating Cultural Expressions from Arabic into English. International Journal of English Linguistics, Vol.3, No.5, pp. 47 and 48 .

Ghazala, Hasan (1995). Translation as Problems and Solution, 7th ed. Beirut, Dar wa Maktabat AL-Hilal, pp. 98 and 195.

Glodjović, Anica (2010). Translation as A Means of Cross-Cultural Communication: Some Problems in Literary Text Translations. Linguistics and Literature, Vol. 8, No 2, pp. 141.

Guerra, Ana Fernández (2012). Translating culture: problems, strategies a practical realities. Art and Subversion, No.1, Lt1, p. 1.

Harzing, Anne-Wil (2016). How to address your teacher? Available at: https://harzing.com/publications/white-papers/how-toaddress-your-teacher. Retrieved on September 23, 2018.

J, Umamaheshwari (ND). Techniques and Method's of Translation. IOSR Journal of Humanities and Social Science (IOSR-JHSS) eISSN: 2279-0837, p-ISSN: 2279-0845, p. 41).

Liu, Dayan (2012). Translation and Culture: Translating Idioms between English and Chinese from a Cultural Perspective. Theory and Practice in Language Studies, Vol. 2, No. 11, p. 2357.

Longman Dictionary of Contemporary English. Available at: https://www.ldoceonline.com/dictionary/pdf. Retrieved on September 24, 2018. Macmillan Dictionary. Available at https://www.macmillandictionary.com/. Retrieved on September 23, 2018.

Munday, Jeremy (2008). Introducing Translation Studies-Theories and Applications, 2nd edition. New York, Routledge, p. 5.

Newmark, Peter (1988). A Textbook of Translation. Hempstead, Prentice Hall Inc, p. 94.

Pym, Anthony, Mar Gutierrez-Colon Plana and Kirsten Malmkjaer (2013). Translation and Language Learning: The role of translation in the teaching of languages in the European Union. A Study. Luxembourg, Publications Office of the European Union, p. 2.

The Free Dictionary. Available at: https://idioms.thefreedictionary.com/. Retrieved on September, 25 th 2018.

Thinking of your memes-Congratulations on your recent release from prison. Available at: https://www.someecards.com/usercards/viewcard/MjAxNC0 zMjM1MjdjZGYzMDQyNmYz/. Retrieved on September, 21st 2018.

Ukpong, Dominica E. (2017). Social and Cultural Barriers in Translation. HSS, VI. 1, pp. 77, 78 and 82.
Writing Greeting Car Messages. Available at: http://sandralamb.com/wpcontent/uploads/2010/04/Greetin gCardMessages.pdf. Retrieved on September, 21st 2018, p. 13. 